\title{
CRUSTAL STRUCTURE OF SOUTHEASTERN MINAS GERAIS, BRAZIL, DEDUCED FROM GRAVITY MEASUREMENTS
}

\author{
D. BLITZKOW \\ P. GASPARINI \\ N.C. DE SÁ \\ INSTITUTO ASTRONÔMICO E GEOFÍSICO - UNIVERSIDADE DE \\ SÃO PAULO - CAIXA POSTAL 30.627 - 01000 - SÃO PAULO - BRAZIL \\ M.S.M. MANTOVANI \\ ON LEAVE OF ABSENCE FROM: INSTITUTO DI GEOLOGIA E GEOFISICA - UNIVERSITY OF NAPOLI - ITALY
}

\begin{abstract}
A gravity survey was carried out in the State of Minas Gerais, between $18^{\circ}$ and $20^{\circ} \mathrm{S}, 42^{\circ}$ and $44^{\circ} 30^{\prime} \mathrm{W}$, utilizing the FIBGE topographic network. These first order data were integrated with other stations where the altitude was measured by barometric methods. The survey was made along profiles with the

aim of extending the crustal informations obtained by an unreversed refraction seismic profile. Bouguer anomalies were inverted by computer techniques which make use of two-dimensional models of arbitrary shape and fitting with experimental data by iterative methods.

\section{RESUMO}

Foi efetuado um levantamento gravimétrico no Estado de Minas Gerais, entre ! $8^{\circ}$ e $20^{\circ} \mathrm{S}, 42^{\circ}$ e $44^{\circ} 33^{\prime} \mathrm{W}$, sobre a rede de nivelamento geométrico da FIBGE. Nos intervalos onde não foram encontradas RNs as altitudes foram determinadas por nivelamento barométrico. O levantamento gravimétrico foi conduzido ao longo de perfis e tem o

objetivo de estender as informações sobre a estrutura crustal, obtidas através de uma prospeç̧ão sísmica a refração não revertida. A inversão das anomalias de Bouguer foi efetuada com técnicas de computação utilizando modelos bi-dimensionais de forma qualquer e ajuste aos dados experimentais por métodos iterativos. Foi obtida uma

A normal depth of $38-40 \mathrm{~km}$ was obtained for the Moho in the area. A crustal thickening was observed between Itabira and Guanhães where the Moho reaches a depth of $45 \mathrm{~km}$.

A lower crustal layer of intermediate density is required from gravity data.

profundidade normal de $38-40 \mathrm{~km}$ para a MOHO.

Entre Itabira e Guanhães, foi observada uma espessura crustal maior e a $\mathrm{MOHO}$ se encontra a uma profundidade de $45 \mathrm{~km}$.

Os dados gravimétricos implicam na existência de uma camada com densidade intermediária na crosta inferior.
\end{abstract}

\section{INTRODUCTION}

Gravity data processed by modern techniques proved to be very useful in preliminary investigations of the main crustal featurs and the crust-upper mantle transitions in different structural environments. In many cases they furnished low cost preliminary crustal models, which were afterwards checked and detailed by more sophisticated and expensive techniques, such as deep seismic soundings (DSS). They bave been used also as a methodology complementary to DSS to extend to a larger area the crustal infor- mations obtained along single DSS profiles.

Successful gravity derived crustal models exist in oceanic areas (e.g. Talwani et al., 1965), island ares (e.g. Makris, 1976), young orogens (e.g. Morelli, 1973; Corrado et al., 1974), pre-Cambrian areas (e.g. Ramberg, 1973).

Quantitative estimates of the crustal thickness in the Brazilian territory are quite scanty at present.

The aim of this paper is to construct a gravity derived preliminary crustal model in the southeastern part of the Minas Gerais State (between $18^{\circ}$ and $20^{\circ} \mathrm{S}, 42$ and $44^{\circ} 30^{\prime} \mathrm{W}$ ), complementing and extending the informations furhished by the only DSS profile up to now existing in that area. This is a 180 km long unreversed profile which was carried out between Itabira and São João Evangelista by a German group directed by $\mathbf{P}$. Gieese, under the sponsorship of the Brazil-Germany agreement for scientific cooperation (Giese, 1975). 
GEOLOGICAL OUTLINE

The surveyed area includes the south-western margin of the São Francisco craton and the neighbouring metamorphic-sedimentary belt formed during the Brazilian cycle (Almeida, 1977), i.e. the latest orogenic cycle which affected a large part of South American in late preCambrian and Eo-Cambrian times (about 600-650 m.y.) (Cordani et al., 1973).

A very simplified geological sketch map is reported in Fig. 1 High grade metamorphic terrains of granulite and amphibolite facies and kinzigitic gneisses are largely predominant. These formations are of Archean (2,0002,600 m.y.) and pre-Cambrian (1,0001,400 m.y.) ages and constitute the oldest outcropping rocks. A pre-Cambrian metasedimentary cover (Espinhaço formation) overlies these rocks in a $\mathrm{N}$-striking region which is located $\mathrm{N}$ of Quadrilatero Ferrifero. A Ntrending reverse fault terminates the Espinhaço formation to the West, where it contacts cabonatitic rocks and metasediments belonging to the Brazilian cycle.

The intermixing of rocks of different metamorphic grade and chemical composition does not allow a reliable estimate of local densities to be used for Bouguer correction in the areas where the basement crops out. A slightly lower density might be used for the stations located on the Espinhaço formation and on Brazilian cycle terrains because in principle the sedimentary cover should have a lower density than the basement, however, as the sediments are generally metamorphosed and its thickness is unknown, it has been preferred to use the same density for the whole area in order to avoid contamination of the results by uncontrolled assumptions. Hence, the average density usually assumed for the upper crust (2.67 g. $\mathrm{cm}^{-3}$ ) has been used for the Bouguer corrections. No correlation between Bouguer anomalies and altitude has been found, even for stations located on the sedimentary cover. This indicates that the chosen density is a re sonable one.

\section{THE GRA VITY SURVEY}

About 300 gravity measurements were made in an area of $50,000 \mathrm{~km}^{2}$. Taking into account the transitability of the region and the aim of the survey, a distribution of the measurement stations along profiles was preferred to a regular network. A distribution along profiles perpendicular to the main geological estructures is particularly suitable for inverting the data by computer techniques which make use of twodimensional models. Three almost parallel NE trending profiles were chosen, as they area approximately perpendicular to the main geological trends (from Curvelo to Couto de Magalhães, from Belo Horizonte to São João Evangelista, from Barão de Cocais to Governador Valadares). Three transversal profiles (from Curvelo to Sabará, from Datas to Guanhães, from São João Evangelista to Governador Valadares) were also carried out. As the aim of the survey was not the investigation of shallow structures a spacing of $5 \mathrm{~km}$ between the stations was considered adequate

The gravity was measured by a Worden, Master type, and two La Coste and Romberg, Model G, gravity meters. The measured values were referred to the base station of Pampulha Airport (Belo Horizonte), for which the IGSN value of:

$$
\mathrm{g}=978.38550 \mathrm{gal}
$$

was used. Gravity values measured by Observatório Nacional (Rio de Janeiro) (Gama, 1972) were also included in the construction of the Bouguer anomaly map (Fig. 1) and the profiles (Fig. 3). These data were also reduced to the IGSN system by connecting some of the Observatório Nacional stations to the Pampulha Airport base station.

The gravity measurements were made on the FIBGE benchmarks available in the region. Further gravity measurements were made on stations where the altitude was determined barometrically by System Pauling altimeters of Instituto de Geociências of USP, by carrying out short circuits closed on FIBGE benchmarks. The accuracy of barometric determinations of altitude is estimated to be better than $+5 \mathrm{~m}$, leading therefore to an overall uncertainity not higher than $1.0 \mathrm{mgal}$ in the Bougher anomalies.

Faye and Bouguer corrections were applied to the measured data. A density of $2.67{\mathrm{~g} . \mathrm{cm}^{-3}}^{-3}$ was used for the Bouguer correction (see discussion in the former section). Topographic corrections were not applied due to the lack of suitable topographic maps. Hovewer station points were chosen generally in such a way as to ensure that topographic effects were not higher than some tenths of a milligal as far as zone $E$ of the Hayford scheme $(560 \mathrm{~m}$.$) . Topographic$ irregularities existing at longer distances are not as prominent as to produce effects higher than $0.2 \mathrm{mgal}$.

Bouguer anomalies were computed with respect to the 1967 gravity reference field. The accuracy of the Bouguer anomaly for each station is esti- mated to be $1.0 \mathrm{mgal}$, which is largely sufficient for the aim of the present paper.

The location of all gravity stations is reported in Fig. 1, where open circles indicate IBGE benchmarks, filled circles indicate stations where the altitude was determined barometrically and triangles indicate the stations measured by Observatório Nacional. A Bouguer map was elaborated (Fig. 1). A listing of coordinates, observed gravity and reduction values for all the stations is available at Instituto Astronômico e Geofísico, USP.

\section{THE BOUGUER ANOMALY MAP}

The prominent feature of the gravity field in the area is a large low of about $-50 \mathrm{mgal}$, which is located between Itabira and Guanhães and is elongated in the same direction as the main geological structures (NNW). The extension of this anomaly indicates that its source must be very deep and it is likely that it is related to the crustupper mantle transition. The center of the anomaly is located in the area where kinzingitic gneisses and amphibolitic facies rocks of the preCambrian Barbacena formation are dominant.

The pattern of the Bouguer anomalies in the surveyed area is quite regular. The only evidences of important discontinuities in the upper crustal layers are a high of about $+30 \mathrm{mgal}$ located SW of Serro and two lows, one located at the western margin of the surveyed area and the other between Governador Valadares and São João Evangelista.

The steepening of the gravity gradient where the profiles C-C' and A$A^{\prime}$ cross the contact between the EoCambrian São Francisco supergroup formations and the Espinhaço formations (Fig. 2) indicates the existence of a major tectonic discontinuity. The occurrence of a similar gradient around Itabira suggests that this tectonic line continues Southeastward, affecting also the area where the basement crops out.

The data reported in Fig. 1 were used for a quantitative evaluation of the depth of the Moho discontinuity and any other possible intracrustal layer.

\section{CRUSTAL MODELS}

The Bouguer anomalies calculated along the profiles A-A', B-B', C-C' and D-D' (see Fig. 1) were smoothed to eliminate the effects of sources lo- 


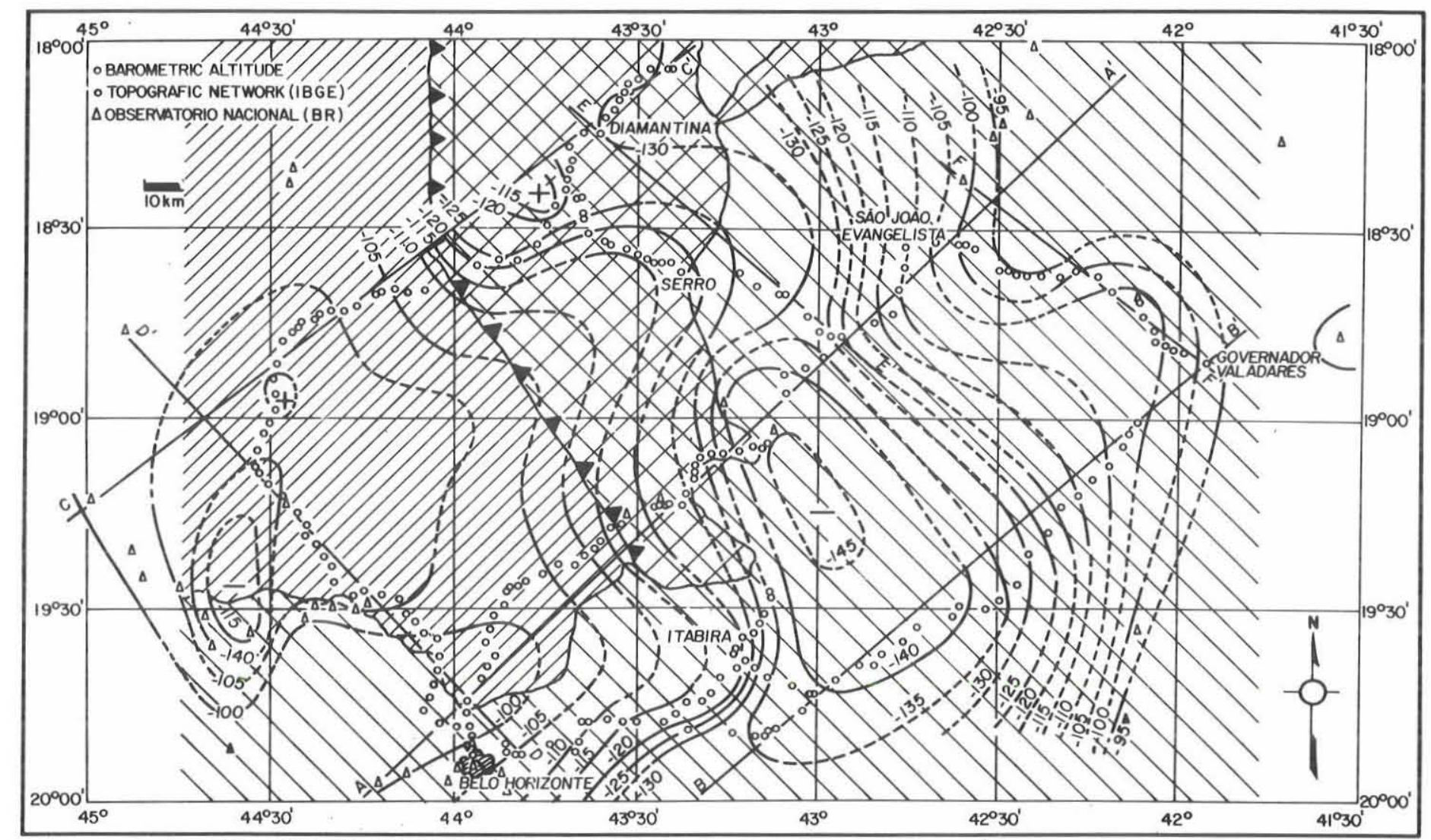

DIIO-CAMBRIAN SĀO FRANCISCO SUPER GROUP (LIMESTONE, DOLOMITES,

LTITES, CALCOPHYLITES, ARDESIAS).

PRE-CAMBRIAN COVER (ESPINHACO SUPERGROUP: QUARTZITES, PHYLLITES,

DPRE-CAMBRIAN AND ARCHEAN BASEMENT (GRANULITES, AMPHIBOLITES, GNEISSES).

Fig. 1 - Bouguer anomaly map and simplified geological sketh. Contour lines interval: 5 mgal.

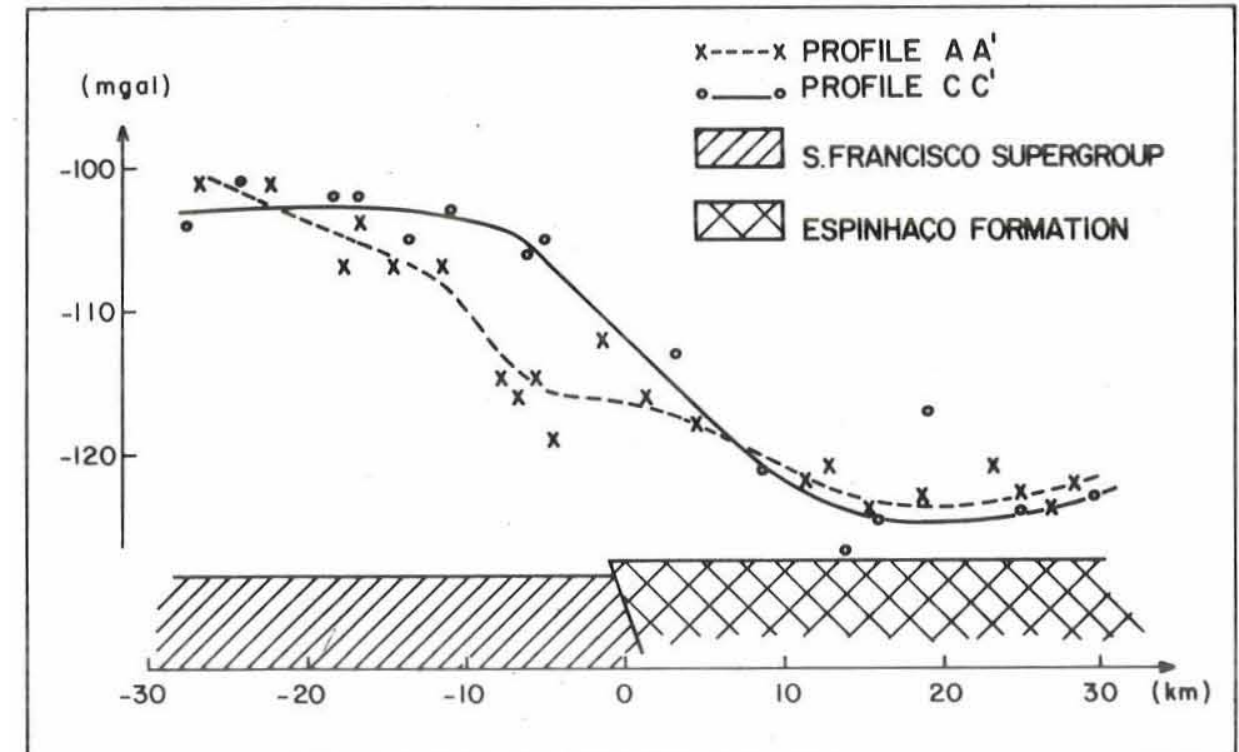

Fig. 2 - Bouguer anomaly profiles through the contact between San Francisco supergroup and Espinhaco formation.

cated within the few uppermost $\mathrm{km}$ of crust. The obtained profiles were then inverted by the computer technique described by Carrara et al. (1974). It consists of the utilization of a twodimensional model of arbitrary poligonal cross section and assigned density contrast. At first,, the gravity field produced by the poligonal body is obtained analytically by means of the Taylor expansion relative to the variable $\mathrm{z}$ (depth), limited to the terms of $1^{\text {st }}$ order. Then the computed gravity is compared with the observed gravity by interative procedures, which make use of a least square method. The best fit relative to the chosen model is so obtained. Given the ambiguity inherent to gravity data interpretation, when the density contrasts are not well known it is convenient that at least the depth of the body be determined by other geophysical methods at some point along the profile, if a reliable solution is desired.

The only additional geophysical data existing in the area, which could help in defining the initial model to be used in the computations, are the $\mathrm{P}$-wave velocity functions obtained by the DSS wnreversed profile (Giese, 1975). Two main P-wave groups were recorded along this profile. A wavegroup with apparent velocities of 6.2 $\mathrm{km} / \mathrm{sec}$ was recorded as firts arrivals as far as the end of the profile (180 $\mathrm{k}: \mathrm{a}$ from the shotpoints). A second group had apparent velocity around 8 $\mathrm{km} / \mathrm{sec}$. The long distance through which the first wave group is recorded as first arrivals indicates that the crust must have constant velocity down to 25-30 km. No wave groups were observed which may indicate a first order discontinuity within the crust. The analysis of the second wave group and the lack of clear phases reflected from the Moho discontinuity suggest that the transition from a velocity around $6.2 \mathrm{~km} / \mathrm{sec}$ to velocities typical of the upper mantle must be continuous and no sharp Moho discontinuity exists. The depth where upper mantle velocities occur was calculated 
at $42 \mathrm{~km}$. Therefore the lowest $14 \mathrm{~km}$ of crust must be characterized by $\mathrm{P}$ wave velocities gradually increasing with depth.

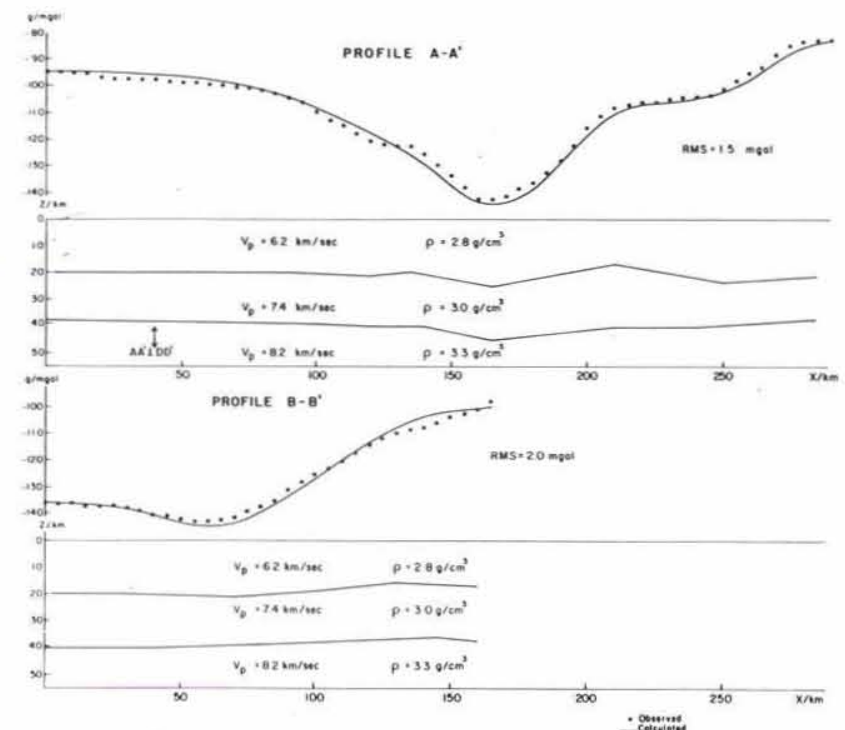

Fig. 3a - Computed crustal models along profiles AA' and BB'. Obs

erved values are compared with curves calculated from the model.

The DSS profile coincides with the northermost part of the A-A' profile (from Guanhães to São João Evangelista). The crustal model used to invert gravity data is represented in Fig. 3. It was constrained to a crustal thickness of $42 \mathrm{~km}$ at Guanhães. The chosen densities are consistent with similar models in other pre-Cambrian areas (e.g. Ramberg, 1973) and with the densities which can be estimated from apparent $P$-wave velocities applying the well-known $\mathrm{Nafe}$ and Drake relationship. Of course the assumption of a well defined lower crustal layer is a schematization of the gradually changing layer suggested by DSS data. The density of 3.0 g. $\mathrm{cm}^{-3}$ is consistent with the average velocity of $7.4 \mathrm{~km} / \mathrm{sec}$ suggested by Giese (1975). The successful models and the computed profiles are reported in Fig. $3 a$, and $b$. Standard deviations between computed and observed values are lower than +2.0 mgal for all the profiles. It must pointed or that the observed data are not compatible with any reliable two-layers model, that is the existence of a lower crustal layer of intermediate density is required to have a good fit with the observed data. The satisfactory fit of the computed with the observed gravity indicates that the low existing between Ilabira and Guanhàes is 10 be ascribed partly to a deepening of the Moho and partly to a deepening of the top of the lower crustal layer. The crust reaches a maximum thickness of $45 \mathrm{~km}$ in this arca, whereas the normal depth all around is $38-40 \mathrm{~km}$. The inclination of the Moho along the seismic profile is not bigher than 3-
4\%. Therefore the apparent P-wave velocities should be quite close to the real velocities. The crustal thickening occurs in a 80-100 km wide NNW a two dimensional model of arbitrary shape indicates that:

a) the normal crustal thickness in the surveyed area is $38-40 \mathrm{~km}$;
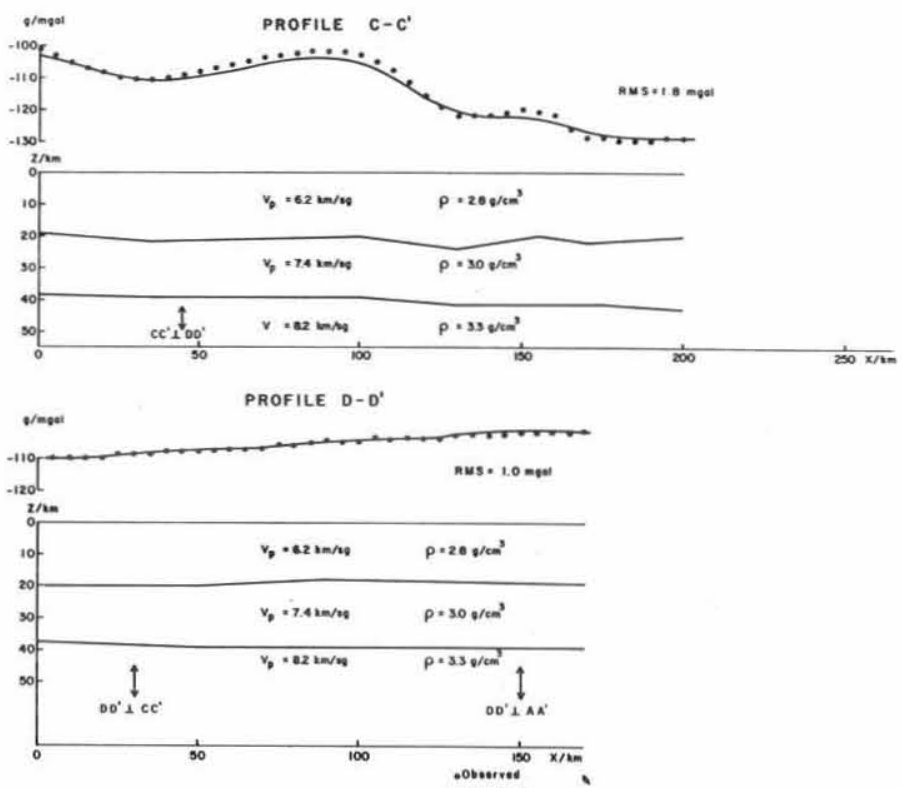

Fig. 3b - Compirted crustal model along profiles CC' and DD'. Obs erved values are compared with curves calculated from the model.

elongated area and it must be related with the compressional tectonic boundary between the Eocambrian São Francisco supergroup and the Espinhaço formations. The highest crustal thickening occurs where medium and high grade metamorphic rocks of the Barbacena formation outcrop. The crustal thickening represents-probably the remnant of an isostatically adjusted pre-Cambrian mountain root. The constant $\mathrm{P}$-wave velocity and the gravity derived model consistently indicate constant physical characteristics of the crust down to $25-30 \mathrm{~km}$ of depth. No major variations of metamorphic grade and/or chemical composition are therefore likely in this depth interval. The normal thickness and the general characteristics of the crust in the surveyed area are close to those observed in other pre-Cambrian areas, such as Canada (Wynne- Edwards, 1972) and Southern Norway (Kanestrøm, 1977).

The lower crustal layer required from the gravity data begins from a depth of 20 to $27 \mathrm{~km}$, according to the schematized model. This layer may be formed by rocks of mafic nature. This inference is supported by the analysis of the long wavelength crustal anomalies of the magnetic field which suggest the existence of a compositional variation toward mafic terms at depth of $22-27 \mathrm{~km}$. (Corrado et al., in press).

\section{CONCLUSIONS}

The inversion of the gravity data by b) a zone of crustal thickening exists between Itabira and Guanhães. It is a $80-100 \mathrm{~km}$ wide NNW trending strip where the crust reaches a thickness of $45 \mathrm{~km}$. The occurrence of a thicker crust in this area is consistent with the existence of a compressional front between the São Francisco supergroup and the Espinhaço formations.

c) the existence of a lower crust of intemediate density is required from gravity data. DSS data suggest however that no first order discontinuity exists within the crust, and that the elastic characteristics of the rocks constituting the lowermost crust approach gradually upper mantle values. If this situation can be schematized by assuming the existence of a lower crustal layer with density of $3.0 \mathrm{~g} / \mathrm{cm}^{3}$, the depth of the top of this layer is normally at $20 \mathrm{~km}$, increasing to $27 \mathrm{~km}$ in the zone of crustal thickening. Greater depths can be computed for the top of this layer if higher densities are assumed.

\section{ACKNOWLEDGEMENTS}

The authors are grateful to Prof. Camil Gemael, coordinator of the Graduation Course in Geodesy at the University of Paraná (Curitiba), who furnished the Worden gravity meter used in this research. The Pauling System altimeters were provided by the Instituto de Geociências, University of S. Paulo, G. Corrado and A. Rapolla, Instituto di Geologia e Geofísica, University of Napoli, Revista Brasileira de Geociências volume 9 
Italy, helped in the interpretation and inversion of data. P. Giese and K.G. Schütte, Institüt für Angewandte Geophysik, Freie Universität, West Berlin, Germany, area acknowledged for having made the results of DSS profile available and having discussed the results with the authors. Dr. Maria Helena Teixeira Mendes and Dr. Clovis C. de Sá (DNPM São Paulo) are acknowledged for having given the authors access to the unpublished geological maps of the surveyed area.

This research was carried out when one of the authors (PG) was visiting professor at IAG-USP with the FAPESP grant n. ${ }^{\circ} 77 / 899$.

\section{REFERENCES}

ALMEIDA, F.F.M. de - 1977 - O craton de São Francisco. Rev. Bras. Geoc., 7: 349-364.

CARRARA, E., IACOBUCCI, F., PINNA, E., RAPOLLA, A. - 1974 - Interpretation of gravity and magnetic anomalies near Napoles, Italy, using computer techniques. Bull. Volc., 38: $1-10$.

CORDANI, U.G., AMARAL, G., KA $\checkmark A S H I$ TA, K. - 1973. The Precambrian evolution of South América. Geol. Rund., 62: 309-317.

CORRADO, G., IACOBUCCI, F., PINNA, E. RAPOLLA, A. - 1974 - Anomalie gravimetriche e magnetiche estrutture crostali nell Italia centro-meridionale. Boll, Geofs. Teor. Appl., 16: 27-291

CORRADO, G., GASPARINI, P., MANTO-
VANI, M.S.M., RAPOLLA, A. (in press) Depth of Curie isotherms and thermal state os the crust in SE Minas Gerais, Brazil, inferred from aeromagnetic data. Rev. Bras. Geoc.

GAMA. L.I. - 1972 - Valores da gravidade na regioes centro e sul do Brasil. Publ. Programa Gravimétrico $n^{\circ} 4$. Observatório $\mathrm{Na}$ cional Rio de Janeiro.

GIESE. P. - 1975 - Preliminary report on the results of seismic measurements in the Brazilian coastal mountains in march/april 1975 Unpubl. Report Brazil-Germany sci. agr.

KANESTRIM, R. - 1977 - Seismic investigations of the crust and Moho in Southern Norway. In; The Norwegian Geotraverse Project, K.S. heier, Ed., Norwegian Research
Council for Science and Umanities. Oslo.

MAKRIS J. - 1976 - A dynamic model of the Hellenic arc deduced from geophysical data. Tectonophys., 36: 339-346.

MOREL.I.I, C. - 1973 - La gravimetria nell'arca italiana. Accad. Naz. Lincei, 183: 297-313.

RAMBERG, I.B. - 1973 - Crustal structures from gravity measurements. Nature Phys. Sci., 240: 149-153.

TAL.WANI, M., I.E PICHON, X., EWING, M. - 1965 - Crustal structures of the Midocena ridgcs. J. Geophys. Res., 70: 341-352.

WYNNE-EDWARDS, H.R - 1972 - The Grenville province. In: Variations in tectonics styles in Canada. R.A. Price and R.J. Douglas Eds., Geol. Assoc. Canada. Spec. Papers, 11: 263-334. 